\title{
Evaluation of Cation Exchange Capacity (CEC) in Tropical Soils Using Four Different Analytical Methods
}

\author{
Fabio Aprile (Correspondence author) \\ Laboratório de Estudos de Ecossistemas Amazônicos - LEEA, Universidade Federal do Oeste do Pará \\ Campus Rondon. Av. Marechal Rondon s/n Caranazal, Santarém, PA, Brazil \\ Tel: 55-93-3064-9066_E-mail: aprilefm@hotmail.com \\ Reinaldo Lorandi \\ Laboratório de Geologia, Departamento de Engenharia Civil - CCT \\ Universidade Federal de São Carlos. Rod. Washington Luiz, km 235 São Carlos, SP, Brazil \\ E-mail: lorandi@power.ufscar.br
}

Received: November 25, 2011 Accepted: December 12, $2011 \quad$ Online Published: May 16, 2012

doi:10.5539/jas.v4n6p278 URL: http://dx.doi.org/10.5539/jas.v4n6p278

The research was partially sponsored by FAPESP $n^{\circ}$ 93/1480-0 and CNPq/Finep $n^{\circ}$ 505085/2004-6.

\begin{abstract}
Four analytical methods for determination of cation exchange capacity (CEC) in tropical soils were tested, aiming to define what the most appropriate based on the requirements: analysis time, degree of reliability and cost of operation. A total of 444 soil samples from the Amazon rainforest and Atlantic rainforest were analyzed in eleven soils types. Organic matter, $\mathrm{pH}$ and ions $\mathrm{Na}^{+}, \mathrm{K}^{+}, \mathrm{Ca}^{2+}, \mathrm{Mg}^{2+}$ and $\mathrm{H}^{+}+\mathrm{Al}^{3+}$ were also analyzed. The influence of the action of fire on the release of ions to the soil was also tested. The results indicated that there was a momentary increase in CEC in the soil after a fire. Tropical soils have a high humidity and acidity, contributing to an overall increase of CEC. Adverse climatic conditions in the tropics affect soil properties, so that practical methods and low cost have the advantage that they can be applied periodically to analyze the quality of the soil.
\end{abstract}

Keywords: CEC, Comparative methodology, Tropical soils, Ions, Organic matter

\section{List of abbreviations}

AC, Alissolo Chromic;

CEC, cation exchange capacity;

$\mathrm{C}_{\text {org, }}$ organic carbon;

FX, Haplic Plinthosol;

GX, Dystrophic Haplic Gleysol;

LA, Dystrophic Yellow Latosol;

LV1, Dystrophic Red Latosol;

LV2, Acrustox Red Latosol;

LVA, Dystrophic Oxisol;

OM, organic matter;

OY, Histosols Mesic;

PVA, Acrisol Dystrophic;

RQ soil rich in quartzite; 


\section{Introduction}

The determination of cation exchange capacity (CEC) is an important tool in studies of erosion, retention of pollutants and waste, and has wide applicability in soil mechanics. Studies on agricultural productivity, includes determining the degree of fertilizer and soil adjustment practices necessary before a crop. The CEC is now widely used in the characterization and study of soil fertility. By analyzing the CEC of a soil, the cost of application of nutrients (NPK) and calcareous can be significantly reduced.

The CEC is defined as the ability of a particle to change positive bases with the environment in which the particle interacts. Cations have the ability to be exchanged for another positively charged ion from the surfaces of clay minerals and organic matter. The most important exchangeable cations in the soil are calcium $\left(\mathrm{Ca}^{2+}\right)$, magnesium $\left(\mathrm{Mg}^{2+}\right)$, sodium $\left(\mathrm{Na}^{+}\right)$, potassium $\left(\mathrm{K}^{+}\right)$, hydrogen $\left(\mathrm{H}^{+}\right)$, aluminum $\left(\mathrm{Al}^{3+}\right)$ and ammonium $\left(\mathrm{NH}_{4}{ }^{2+}\right.$ ), The CEC can directly influence the changes in soil $\mathrm{pH}$, because every time the clay particles capture cations release $\mathrm{H}^{+}$and $\mathrm{Al}^{3+}$ ions, which in high concentrations acidifies soil. Generally, tropical soils have low CEC, especially for high sandy and low $\mathrm{pH}$ soils. Minerals as oxides of aluminum, iron and manganese that are very abundant in tropical soils also contribute to the low CEC. In these cases a greater investment in fertilization, especially with humic compounds becomes necessary.

There are several methods for determining the cation exchange capacity in soils and sediments, including classical methods by titration with or without control of $\mathrm{pH}$ of the solution (Bascomb, 1964; EMBRAPA, 1987; Jackson, 1962; Pejon, 1992) through the nephelometric method (Adams and Evans, 1979), use of radioactive isotopes (Francis and Grigal, 1971), complexation and cation exchange method using salts of barium, copper or magnesium (Bergaya and Vayer, 1997; Méier and Kahr, 1999; Tucker, 1954), or the comparative analysis of the cations $\mathrm{Na}^{+}, \mathrm{K}^{+}$and $\mathrm{Mg}^{2+}$ of the calcareous soils and clays by atomic absorption spectrophotometry (AAS) (Dohrmann, 2006a,b). Of all the known methods, the ammonium acetate method of Lewis (1949) is the most widely used method which is very effective not only for clay soils but also for sandy soils containing insoluble elements such as quartz, mica and feldspar. The major difference, however, is to use a method that is fast, reliable and of low cost, allowing analysis of a large number of samples in a single sequence.

The methods for determining the CEC can be classified into direct and indirect analysis. The method of direct determination is based on the saturation of exchange complex with a cation of reference, followed by their extraction and analysis, while the indirect method of determination is based on analysis and further sum of exchangeable bases extracted into solution with control $\mathrm{pH}$. This study is aimed to analyze the cation exchange capacity in different tropical soils of the Amazon and Atlantic rainforest, applying four methods in order to identify the most appropriate method for the tropics, based on the time for analysis, degree of reliability and cost of operation.

\section{Material and Methods}

\subsection{Study Area}

For comparative analysis of methodologies soils of the Amazon rainforest and Atlantic rainforest (Mata Atlântica) were used. In Amazon rainforest the area of soil sampling was concentrated on Sustainable Development Reserve of Tupé - SDR Tupé $\left(02^{\circ} 57^{\prime}-03^{\circ} 03^{\prime} \mathrm{S}\right.$ and $60^{\circ} 12^{\prime}-60^{\circ} 19^{\prime} \mathrm{W}$, Figure 1), located at the left margin of Negro River, located at about $25 \mathrm{~km}$ straight from the Manaus city (Amazonas State, Brazil), at an average altitude $20 \mathrm{~m}$ above sea level, and a total area of 11973 hectares. The SDR Tupé is covered by dense rainforest and in accordance with Radam-Brazil (1978) were identified three phytoecological regions evidenced by classes: Campinarana formations, Dense Tropical Forest and Open Tropical Forest, and further flooded areas of accumulation. According to Köppen (1948), the climate of the region is mostly classified as "Am" constantly hot and humid, with average annual temperature of $28 \pm 4{ }^{\circ} \mathrm{C}$, and rainfall mostly occurring between December and April with an average of $2210 \mathrm{~mm} \mathrm{yr}^{-1}$.

\section{$<$ Figure 1 $>$}

Soil samples were also collected from the campus of Federal University of São Carlos - UFSCar $\left(21^{\circ} 58^{\prime}-21^{\circ} 59.5^{\prime} \mathrm{S}\right.$ and $47^{\circ} 52^{\prime}-47^{\circ} 53.2^{\prime} \mathrm{W}$, Figure 2) lying in one of the last areas of Atlantic rainforest of Southeastern Brazil. It is located on very jagged highlands to the North and South by lines of cliffs, at an average altitude of $850 \mathrm{~m}$ above sea level, with a total area of 710 hectares. Today little of the original vegetation remains in the sampled area, which was composed of Mesofoliada Forest, Araucaria Forest and grassland and scrubs in the lower regions. Agricultural and pastoral areas are found partly invaded by typical vegetation of Cerrado. According to Köppen (1948) the climate is mostly classified as "Cwa" subtropical with dry winter and 
hot summer. The average annual temperature is $21{ }^{\circ} \mathrm{C}$. The rainy season occurs between October and March, concentrating $81 \%$ of the total annual rainfall of approximately $1520 \mathrm{~mm}$ on average.

$<$ Figure $2>$

\subsection{Methodological Procedures}

The sampled soils were classified according to the Brazilian System of Soil Classification (SiBCS) based on the work of EMBRAPA (1999, 2005). In the Amazon rainforest were identified and sampled the following soils: Dystrophic Yellow Latosol (LA); Dystrophic Oxisol (LVA); Alissolo Chromic (AC); Acrisol Dystrophic (PVA), and Haplic Plinthosol (FX, Figure 1). In addition, sediments from sandy ridges (Sd) that extend to the left bank of the Negro River on the edge of SDR Tupé were sampled. In the area of Atlantic rainforest were identified and sampled the following soils: Dystrophic Oxisol (LVA); Dystrophic Red Latosol (LV1); Acrustox Red Latosol (LV2); Histosols Mesic (OY); Dystrophic Haplic Gleysol (GX), and soil rich in quartzite (RQ, Figure 2).

Soils were sampled at 12 locations inside the Amazon rainforest and 25 locations in the Atlantic rainforest. At each location, samplings were made at each meter from the surface to five meters deep (total 6 depths). Locations that were not altered by the presence of roads and trails or by flooding were chosen. From every location two subsamples were taken for the test comparing the methods adopted. A total of 144 subsamples for soils of the Amazon rainforest (12 locations x 6 depths x 2 subsamples) and 300 subsamples for soils of the Atlantic rainforest $(25 \times 6 \times 2)$ were analyzed, which were dried at $55{ }^{\circ} \mathrm{C}$ and passed through a sieve of $2 \mathrm{~mm}$ mesh size before application of analytical procedures.

Soil organic matter (OM) was determined by acid extraction method (Jackson, 1962) by placing $100 \mathrm{~g}$ of soil in a beaker with $50 \mathrm{ml}$ of $30 \%$ hydrogen peroxide and warming at $80{ }^{\circ} \mathrm{C}$, making additions to $\mathrm{H}_{2} \mathrm{O}_{2}$ when necessary. The calculation of the amount of organic matter was done by the difference in mass of dry sample before and after oxidation. The organic carbon $\left(\mathrm{C}_{\text {org }}\right)$ was determined by Walkley-Black procedure (Jackson, 1962; EMBRAPA, 1987), in which the sample is digested with potassium dichromate $\left[\mathrm{K}_{2} \mathrm{Cr}_{2} \mathrm{O}_{7}\right]$ and concentrated sulfuric acid. The solution was titrated against ammonium ferrous sulfate $\left[\mathrm{Fe}\left(\mathrm{NH}_{4}\right)_{2}\left(\mathrm{SO}_{4}\right)_{2} \cdot 6 \mathrm{H}_{2} \mathrm{O}\right]$, using diphenylamine indicator. The concentrations of sodium, potassium, calcium, magnesium and aluminum $\left(\mathrm{mmol}_{\mathrm{c}} \mathrm{kg}^{-1}\right)$ in the samples were determined by AAS. Following are the description of analytical procedures of the four methods used for determining the CEC.

\subsubsection{Method 1: Determination of CEC by adsorption of methylene blue}

Methylene blue is an organic and cationic dye, and according to the "Merck Index" shows the composition $\mathrm{C}_{16} \mathrm{H}_{18} \mathrm{~N}_{3} \mathrm{SCl} .3 \mathrm{H}_{2} \mathrm{O}$, named hydrochloride metiltiamina. The method of adsorption of methylene blue is based on the procedure cited by Pejon (1992), and allows both the determination of CEC and specific surface of clay minerals. Methylene blue solution was prepared in a balloon by adding $1.5 \mathrm{~g}$ of dye to 1 liter of distilled water, and thoroughly shaken to obtain a homogeneous solution. Two grams of soil was placed in a $50 \mathrm{ml}$ beaker containing $10 \mathrm{ml}$ of distilled water and, stirred vigorously. The methodological assay began by adding $0.5 \mathrm{ml}$ of methylene blue solution to the beaker containing the soil mix. After 3 minutes, a drop of the suspension material was removed with a glass rod, and deposited it on Millipore filter paper. When a light blue halo around the dark patch of soil appears on the filter paper, the test is over. The calculation of CEC was obtained by equation 1 (Zuquette et al., 1987).

$$
C E C=\frac{V x C \times 100}{M}
$$

where: CEC $\left(\mathrm{mmol}_{\mathrm{c}} \mathrm{kg}^{-1}\right)$; $\mathrm{V}$ is the volume consumed of methylene blue solution $(\mathrm{ml})$; $\mathrm{C}$ is the concentration of methylene blue solution $(\mathrm{N})$, and $\mathrm{M}$ is the mass dry soil $(\mathrm{kg})$.

\subsubsection{Method 2: Determination of CEC by methylene blue with $\mathrm{pH}$ control}

For the determination of CEC the Georgim Kaolin Ltd, method in accordance with procedures established by the Manu al of Methods of Soil Analysis EMBRAPA (1987), which allows to calculate both the cation exchange capacity and the specific area. In a $500 \mathrm{ml}$ erlenmeyer flask was weighed $0.5 \mathrm{~g}$ of soil sample was taken to which $300 \mathrm{ml}$ of deionized water was added. The solution was mechanically agitated to form a homogeneous mixture. For Oxisols it is suggest the addition of three drops of $0.5 \mathrm{~mol} \mathrm{l}^{-1}$ of $\mathrm{Na}_{2} \mathrm{CO}_{3}$ to increase homogeneity. Then the $\mathrm{pH}$ of the suspension was reduced with a standard solution methylene blue $\left(3.7 \mathrm{~g} \mathrm{l}^{-1}\right)$ in a $1: 1$ ratio with the mixture. After each addition, the suspension was stirred for two minutes and after was placed a drop of suspension material in a Millipore filter paper. This procedure continued until a light blue halo around the dark patch of soil on the filter paper appeared. The calculation of CEC was obtained by equation 2 . 


$$
C E C=\frac{V \times 100}{M}
$$

where: $\mathrm{V}$ is the consumed volume of methylene blue in mmol, and $\mathrm{M}$ is the mass of dry soil sample $(\mathrm{kg})$.

\subsubsection{Method 3: Determination of CEC Using of Acetic acid}

According to Jackson (1962), CEC of the soil can be estimated in presence of acetic acid, and the change of $\mathrm{pH}$ measured to determine the amount of $\mathrm{H}^{+}$removed from solution by comparison with a calibration curve of the $\mathrm{pH}$ of acetic acid. Initially, it was prepared a $1 \mathrm{~mol}^{-1}$ acetic acid solution with deionized water and its $\mathrm{pH}$ was determined. Then a $2.5 \mathrm{~g}$ of soil, was placed in a $50 \mathrm{ml}$ beaker with $25 \mathrm{ml}$ of acetic acid, and stirred for a period of one hour using a mechanical shaker. After agitation, the mixture was left undisturbed for complete sedimentation of the soil particles. Then the $\mathrm{pH}$ of the supernatant was read, which was the same of the mixture practically. The $\mathrm{pH}$ of the acetic acid solution was also determined simultaneously. This method could also be used for sediments. The calculation of CEC was obtained by the equation 3 (Jackson, 1962).

$$
\frac{C E C}{M}=(p H \text { observed }-p H \text { acetic acid }) \times 22
$$

where: $\mathrm{CEC}=\mathrm{mmol}_{\mathrm{c}} \mathrm{kg}^{-1}$ of exchangeable metal cations, and $\mathrm{M}$ equals $0.1 \mathrm{~kg}$ of dry soil or sediment.

\subsubsection{Method 4: Determination of CEC by Ammonium Acetate}

The ammonium acetate method described by Truth (1956) is a method of direct calculation. In a $50 \mathrm{ml}$ erlenmeyer flask a $2.5 \mathrm{~g}$ of soil sample was taken to which $25 \mathrm{ml}$ of $1 \mathrm{~N}$ ammonium acetate was added and left undisturbed for 5 minutes. Later successive washes were performed with $25 \%$ ethyl alcohol. The ammonia retained was removed with $100 \mathrm{ml}$ of solution $1 \mathrm{~N} \mathrm{NaCl}$ plus $0.005 \mathrm{~N} \mathrm{HCl}$. The $\mathrm{pH}_{\text {mis }}$ of the mixture was determined in a soil:water:buffer mixture (1.0:2.5:0.5), and the $\mathrm{H}^{+}+\mathrm{Al}^{3+}$ concentrations were obtained from the sum of the bases of CEC by $1 \mathrm{~N}$ ammonium acetate in $\mathrm{pH}$ 7.0. A linear regression curve was prepared between $\mathrm{pH}_{\text {mis }}$ and $\mathrm{H}^{+}+\mathrm{Al}^{3+}$. With the values of $\mathrm{H}^{+}+\mathrm{Al}^{3+}$ obtained by the equation 4 and the sum of bases extracted with $0.05 \mathrm{~N} \mathrm{HNO}_{3}$, it was calculated the values of CEC by the equations 5 and 6.

$$
\log (H+A l)=3.76-0.53 \times H_{m i s}
$$

where: $\mathrm{pH}_{\text {mis }}$ is the $\mathrm{pH}$ of the relation soil:water:buffer.

$$
(\mathrm{H}+\mathrm{Al})-\left(\mathrm{NH}_{4} \mathrm{OA} \mathrm{c}_{\mathrm{c}}\right)=1.126(\mathrm{H}+\mathrm{Al})-0.764
$$

where: $\mathrm{NH}_{4} \mathrm{OA}_{\mathrm{c}}$ is the volume of ammonium acetate $(\mathrm{ml})$.

$$
\mathrm{CEC}-\left(\mathrm{NH}_{4} \mathrm{OA}_{c}\right)=1.155 \mathrm{CEC}-1.253
$$

For comparison of the results of CEC to the methods that do not have a control the results were adjusted to neutral $\mathrm{pH}(\mathrm{pH}=7.0)$, allowing linear regression analyses between the four methods tested. The CEC results obtained for the types of soils were analyzed under the descriptive aspect, in order to verify their measures of central tendency and variability. To check the magnitude and direction of the association between the methods tested, two methods, without any degree of dependence was taken and Pearson correlation coefficient (r), was performed to evaluate the degree of dependence of the ionic components applied to linear regression.

\section{Results}

Table 1 summarizes the results obtained of CEC and organic carbon and its relationship to $\mathrm{pH}$ and major ions that comprise the cation exchange capacity of the soil. The CEC values ranged from $8.61 \mathrm{mmol} \mathrm{kg}^{-1}$ in the sandy soil (Sd) found on the left bank of the Negro River, and $62.25 \mathrm{mmol} \mathrm{kg}^{-1}$ in Dystrophic Yellow Latosol (LA) located in the SDR Tupé, both soils of the Amazon rainforest. The Oxisol soils had the highest values of CEC, and there may be a strong correlation of CEC with the high concentrations of clay present in these soils, since the clay on its surface has a strong negative charge, which attract positively charged cationic elements. The Oxisols of the Amazon region, especially in the area of the floodplain, whose sediments are derived from the Andean and Pre-Andean regions, have a high concentration of iron $\left(\mathrm{Fe}^{2+} / \mathrm{Fe}^{3+}\right)$, and other metallic elements, all strongly aggregated to particles of clay. It is considered the cation exchange capacity of a soil as the sum of all exchangeable bases. In this condition, the main exchangeable bases in both environments studied were the complex $\mathrm{H}^{+}+\mathrm{Al}^{3+}$ and $\mathrm{Ca}^{2+}$ ions.

Among the variety of soils analyzed, the results showed that the sandy ridges $(\mathrm{Sd})$ on the margins of the Negro River, in the Amazon rainforest, had the lowest CEC, which means that these soils have low ion exchange capacity with plant roots, imposing an ecological pressure that allows only the growth of creeping plants, and 
some grasses. On the other hand, the soils LA, LV and LVA ensure a greater flow of ions of soil to plant roots, creating favorable conditions for the emergence of a diverse floristic composition. That floristic composition contributes with residues (leaves, twigs, fruits) to form a litter layer rich in organic matter on the soil, further increasing the cation exchange capacity.

Tropical soils are generally acidic, as demonstrated by the analysis of $\mathrm{pH}$ (Table 1), interfering with the ion exchange especially in environments rich in organic matter, either occurring naturally or by fertilization. There is a strong relationship between the $\mathrm{CEC}$ and the $\mathrm{pH}$ of the soil, as the soil $\mathrm{pH}$ increases with the increasing concentrations of CEC. This is a very important condition for cultivated areas in tropical regions where the soil is usually acidic. Correction of the soil $\mathrm{pH}$ with calcareous to 6.5 , for example, facilitates the increase of cation exchange, allowing greater absorption of nutritional elements (macro and micronutrients) by plant roots. Among the most favored element is the phosphorous, the maintenance of soil $\mathrm{pH}$ close to neutral condition provides an optimal cation exchange capacity condition to bioavailability of phosphorus.

$<$ Table 1>

The main determinants of CEC are clay and organic matter. This is because both have a negative electric charge strong enough to attract the positively charged cationic elements. Soils with different contents of clay minerals and organic matter have different values of CEC. The Pearson's correlation analysis presented in Figure 3 confirmed that there was significant correlation between CEC and organic elements, organic matter $\left(\mathrm{R}^{2}=0.7123\right.$ and Pearson $r=0.8440)$ and organic carbon $\left(R^{2}=0.7139\right.$ and Pearson $\left.r=0.8449\right)$, showing that soils rich in organic matter have high values of CEC. The points that were different from the curve were identified as belonging to the soil Dystrophic Haplic Gleysol (GX) and Dystrophic Yellow Latosol (LA).

$<$ Figure 3>

Correlation analyses were applied to the four methods tested in pairs, to assess the degree of association between the methods (Figure 4). The results indicated that the correlations made between the methods $1 \times 2$ (Figure 4A) and between the methods $1 \times 4$ (Figure 4C) were the most significant, with $\mathrm{R}^{2}=0.9646$ and $\mathrm{R}^{2}=0.9671$, respectively. On the other hand, all the correlations involving the method 3 showed the lowest degree of significance, probably due to high variation of results obtained by this method. The preliminary results presented in Figure 4 suggest that any of the methods 1, 2 or 4 could be adopted without significant loss of information for the analysis of CEC.

$<$ Figure $4>$

With respect to the analytical methods used to determine the cation exchange capacity of the soils, analyzing Figure 5, it can be noted that the four methods tested had a very similar trend to the response depending on the type of sample. However, a closer examination revealed that methods 1 and 4 showed, in most samples, the highest concentrations of CEC in mmol. $\mathrm{kg}^{-1}$, often with overlapping results. On the other hand, Method 3 had always as a result concentrations below the levels determined by the other methods, indicating there could be loss of sensitivity for detecting the levels of CEC in the analysis. The losses were more significant for the soils riches in quartzite (RQ) and sandy soils (Sd), where the levels of CEC were naturally lower for all four methods tested. The RQ and Sd soils have, under natural conditions, low levels of organic compounds and clay minerals, with predominance of quartzite, silt and mud. Therefore, the method adopted must have good sensitivity to determine low concentrations of CEC. Another important aspect shown in Figure 5 is that the methods 3 and 4 had high variation of concentration of CEC in relation to the results obtained by the other methods (methods 1 and 2). The hypothesis of contamination of samples can not be discarded. However, since the variation of results was not constant for all samples, nor for the four methods used, it must be assumed that the loss of sensitivity in the detection of the methods 3 and 4 is the most coherent explanation. The variation in results may be associated with the fact that Methods 3 and 4 require a control of the $\mathrm{pH}$ of the mixture [solution + soil sample], so that an error by the operator or an inability to stabilize the $\mathrm{pH}$ of the mixture may cause variations mentioned.

$<$ Figure 5>

\section{Discussion}

Knowledge of the CEC in the soil can be of great importance to characterize the soil on the content of ionic elements, concentration of clay and mud, texture, degree of compression levels of porosity and permeability, and supply information about the possible need for fertilizer and correction of the soil acidity.

The CEC is an important soil property. High CEC may indicate high levels of clay, low permeability and internal drainage, due to high soil compaction. Already low levels of CEC may indicate a soil texture ranging from clay-sandy to sandy, with variable grain size and high permeability. Soils with low CEC, when they receive large 
volumes of rainwater to leech some of the ionic elements distributed in the A horizon by leaching, leaving the soil depleted in nutrients. It is for this reason that sandy soils lose much more ionic elements (free form), which could be distributed to plant nutrition, than the clay soils and/or rich in organic compounds. Sandy soils of the Cerrado of the Amazon, whose $\mathrm{pH}$ ranges from slightly acid to acid, as leachate soils with low organic matter and clay, have few colloids or aggregate to retain the elements in ionic form, and therefore should receive fertilizer in levels largest and most fractionated before a crop. In these cases, the practice of fertilization is not enough, because the ions will not be held by the soil in case of rain. It is necessary with the application of a fertilizer to practice the introduction of plant cover (live coverage and/or mulch) which is essential to protect leaching of the soil, thus increasing the capacity of cation exchange in crops. Soils with organic matter percentage above $17 \%$ are classified as organic soils, and have high CEC, raising the nutritional potential of the surface layers of soil. Generally, soils with high CEC have color ranging from dark brown to black due to the high lignin content of organic matter. This soil with high organic matter content is not necessarily productive for agriculture.

The correct determination of the CEC of a soil is difficult due to several methodological problems. CEC is strongly dependent on physical-chemical variables such as $\mathrm{pH}$, salinity and alkalinity of the soil, and partly independent of temperature, pressure, composition and concentration of electrolytes (Bache, 1976). Considering factors such as an occasional rain, sunshine with increased loss of soil humidity or burning all can change the physical-chemical properties of soil, even briefly. The determination of the CEC should be understood as a momentary estimate of the composition cationic elements of the soil. Practice of burning of the Amazon forest affect the concentrations of aluminum in the soil after the fire, making the soil temporarily more acidic with high levels of ionic elements available, as shown in Figure 6, which presents a linear regression analysis between $\mathrm{H}^{+}-\mathrm{Al}^{3+} / \mathrm{Ca}^{2+}$ and CEC in Dystrophic Oxisol (LVA) of the Amazon floodplain, before and after the burning of a stretch of forest. The results of the analyses showed that the levels of $\mathrm{Ca}^{2+}$ and $\mathrm{H}^{+}+\mathrm{Al}^{3+}$ had an increases in their concentrations in the soil immediately after the fires, which play a crucial role in the release into the soil of the elements retained in the plants that made the vegetation of the area. The average increase in $\mathrm{Ca}^{2+}$ concentration was $35.9 \%$, and to the complex $\mathrm{H}^{+}+\mathrm{Al}^{3+}$ the average increase was $12.9 \%$. The $\mathrm{CEC}$ had an average increase of $18.6 \%$, although it is possible that this increase in ionic concentration of the soil is only momentary, so that settling processes of decomposition, bacterial uptake and germination of seedlings, the ionic charge of the land return to its normal balance. There was an intense loss of the ionic charge of the soil to the environment by the action of winds and rain water, which transport ions along with the ashes of burned to streams and rivers. The idea that the ionic concentrations in the soil increase with burns, has contributed to the maintenance of this practice in many tropical regions. However, besides the fact that the ionic concentrations rise only briefly, which can be removed from the soil by external actions (wind and rain), there is the problem of destruction of macro and microorganism responsible for process decomposition and nutrient cycling by the action of fire. In other words, burning helps the loss of soil productivity, loss of ions and destruction of decomposing organisms, revealing a false increase of CEC in soils immediately after the action of fire.

\section{$<$ Figure 6>}

Soils containing high content of calcite, a mineral very common in tropical areas, release $\mathrm{Ca}^{2+}$ in favorable conditions of soil moisture and $\mathrm{pH}$, resulting in abnormal results in the analysis of CEC. According to Dohrmann (2006b), the determination of CEC in samples containing carbonate minerals such as calcite and dolomite, is problematic because the $\mathrm{Ca}^{2+}$ released by dissolution of carbonates during the analysis of CEC affects the accuracy of results. Soils containing minerals illite and vermiculite do not exchange their cations easily and immediately (Malcolm \& Kennedy, 1969), requiring a very restricted acidic condition to occur change. CEC analysis methods that use $\mathrm{pH}$ control (buffering) to determine the concentration of cations can not determine the correct concentration of CEC. Methods that make use of chloride salts or barium carbonate to determine the CEC must have the calculations corrected for possible analysis in calcareous soils.

An evaluation of the cost analysis of the studied methods it showed that the costs for sample varied between US\$ 27.90 for the method 1, US\$ 31.41 for the method 2, US\$ 36.36 for the method 3, and US\$ 41.54 for the method 4 , including the cost of energy, reagents and equipments of operation. Thus, considering the analysis time, degree of reliability and cost of operation, the proposed objectives to determine the best method of analysis of CEC, the results indicated that the more simpler and practical method, with low operating costs, faster to process, and does not require control of $\mathrm{pH}$ indicator solution (methylene blue), nor the mixture (solution + soil) was the method 1. The results obtained also show that the method 1 presented a lower variation in the concentrations of CEC inside the same group of soils and group of samples, indicating good sensitivity for analysis. There are several methods for determining the CEC, as previously mentioned, and some of these 
methods are fairly accurate and sensitive as the colorimetric method and atomic absorption spectrophotometry. However, the proposal was to find a simple and low cost of operation method, which allows to us to present significant results with an acceptable margin of error. In this condition, the method 1 proved to be a versatile and sensitive to variations in the concentrations of CEC for tropical soils.

The CEC is an important indicator of soil properties. However, but there are several intrinsic properties of the soil, already discussed, that may interfere with ion concentration and therefore the values of CEC, giving a false interpretation of the results. Practical and low cost methods have advantage because they can be applied quickly for many soil and sediment samples, allowing routine identification of the soil quality that you want to work. This work confirmed the importance of the CEC to manage soil properties, including the availability of nutrients.

\section{Acknowledgements}

The authors thank the technicians and researchers of the Laboratory of Geology of the UFSCar and the Water Chemistry Laboratory of INPA, where they were processed for analysis; and the reviewers of the manuscript by the comments and suggestions. The authors also thank FAPESP No. 93/1480-0 and CNPq/Finep $\mathrm{n}^{\circ}$ 505085/2004-6 processes for technical support and grant funding.

\section{References}

Adams, J. M., \& Evans, S. (1979). Determination of the cation-exchange capacity (layer charge) of small quantities of clay minerals by nephelometry. Clays and Clay Minerals, 27, 137-139. http://dx.doi.org/10.1346/CCMN.1979.0270210

Bache, B. W. (1976). The measurement of cation exchange capacity of soils. Journal of the Science of Food and Agriculture, 27, 273-280. http://dx.doi.org/10.1002/jsfa.2740270313

Bascomb, C. L. (1964). Rapid method for the determination of the cation exchange capacity of calcareous and non-calcareous soils. Journal of the Science of Food and Agriculture, 15, 821-823. http://dx.doi.org/10.1002/jsfa.2740151201

Bergaya, F., \& Vayer, M. (1997). CEC of clays; measurement by adsorption of a copper ethylenediamine complex. Applied Clay Science, 12, 275-280. http://dx.doi.org/10.1016/S0169-1317(97)00012-4

Dohrmann, R. (2006a). Cation exchange capacity methodology I: An efficient model for the detection of incorrect cation exchange capacity and exchangeable cation results. Applied Clay Science, 34, 31-37. http://dx.doi.org/10.1016/j.clay.2005.12.006

Dohrmann, R. (2006b). Cation exchange capacity methodology III: Correct exchangeable calcium determination of calcareous clays using a new silver-thiourea method. Applied Clay Science, 34, 47-57. http://dx.doi.org/10.1016/j.clay.2006.02.010

EMBRAPA - Empresa Brasileira de Pesquisa Agropecuária. (1987). Manual de Métodos de Análise de Solos. Rio de Janeiro: EMBRAPA-CNPS. 211 pp.

EMBRAPA - Empresa Brasileira de Pesquisa Agropecuária. (1999). Centro Nacional de Pesquisa de Solos. Sistema brasileiro de classificação de solos. Brasília, DF: Embrapa Produção da Informação; Rio de Janeiro: Embrapa Solos. 412 pp.

EMBRAPA - Empresa Brasileira de Pesquisa Agropecuária. (2005). Plano diretor da Embrapa Solos 2004-2007. Rio de Janeiro: Embrapa Solos. 36 pp.

Francis, C. W., \& Grigal, D. F. (1971). A rapid and simple procedure using ${ }^{85} \mathrm{Sr}$ for determining cation exchange capacities of soils and clays. Soil Science, 112, 17-21. http://dx.doi.org/10.1097/00010694-197107000-00004

Jackson, M. L. (1962). Soil Chemical Analysis. New York: Prentice-Hall Inc. 498 pp.

Köppen, W. (1948). Climatologia; con un estúdio de los climas de la tierra. Fonde de Cultura Económica, México.

Lewis, D. R. (1949). Analytical data on reference clay materials. Sect. 3, Base-exchange data. 1950, American Petroleum Institute Project 49 Clay Mineral Standards, Preliminary Report 7. pp. 91.

Malcolm, R. L., \& Kennedy, V. C. (1969). Rate of cation exchange on clay minerals as determined by specific ion electrode techniques. Soil Sci. Soc. Am. Proc., 34, 247-253. http://dx.doi.org/10.2136/sssaj1969.03615995003300020024x 
Meier, L. P., \& Kahr, G. (1999). Determination of the cation exchange capacity (CEC) of clay minerals using the complexes of copper (II) ion with triethylenetetramine and tetraethylenepentamine. Clays and Clay Minerals, 47, 386-388. http://dx.doi.org/10.1346/CCMN.1999.0470315

Pejon, O. J. (1992). Mapeamento geotécnico da folha de Piracicaba-SP (escala 1:100.000): estudo de aspectos metodológicos, de caracterização e de apresentação dos atributos. Departamento de Geotecnia, Escola de Engenharia de São Carlos, USP, São Carlos, 2v. 224 pp. (Thesis)

Radam Brasil. (1978). Levantamento de recursos naturais. Folha AS.20 Manaus. Rio de janeiro, Departamento Nacional de Produção Mineral.

Tucker, B. M. (1954). The determination of exchangeable calcium and magnesium in carbonate soils. Aust. J. Agric. Res., 5, 706-715. http://dx.doi.org/10.1071/AR9540706

Verdade, F. C. (1956). Observação sobre métodos de determinação da capacidade de troca de cátions do solo. Bragantia, 15, 393-401. http://dx.doi.org/10.1590/S0006-87051956000100029

Zuquette, L. V. (1987). Análise da cartografia geotécnica e proposta metodológica para condições brasileiras. Departamento de Geotecnia, Escola de Engenharia de São Carlos, USP, São Carlos, 3v. 657 pp. (Thesis)

Table 1. Chemical characteristics of soils analyzed based on the soil classification map presented in figures 1 and 2.

\begin{tabular}{|c|c|c|c|c|c|c|c|c|c|}
\hline & Soil & $\begin{array}{c}\text { CEC } \\
\left(\mathrm{mmol} \mathrm{kg}^{-1}\right)\end{array}$ & $\begin{array}{c}\mathbf{C}_{\text {org }} \\
\left(\mathrm{g} \mathrm{dm}^{-3}\right)\end{array}$ & pH & $\begin{array}{c}\mathrm{Na}^{+} \\
\left(\mathrm{mmol} \mathrm{kg}^{-1}\right)\end{array}$ & $\begin{array}{c}\mathbf{K}^{+} \\
\left(\mathrm{mmol} \mathrm{kg}{ }^{-1}\right)\end{array}$ & $\begin{array}{c}\mathbf{C a}^{\mathbf{2 +}} \\
\left.(\mathrm{mmol} \mathrm{kg})^{-1}\right)\end{array}$ & $\begin{array}{c}\mathbf{M g}^{\mathbf{2 +}} \\
\left.(\mathrm{mmol} \mathrm{kg})^{-1}\right)\end{array}$ & $\begin{array}{c}\mathbf{H}^{+}+\mathbf{A l}^{3+} \\
\left(\mathrm{mmol} \mathrm{kg}^{-1}\right)\end{array}$ \\
\hline \multirow{6}{*}{ 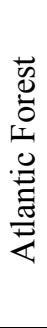 } & LVA & 58.79 & 26.74 & 4.59 & 1.10 & 1.96 & 9.20 & 3.40 & 45.77 \\
\hline & LV1 & 43.55 & 19.31 & 4.71 & 0.88 & 1.72 & 6.90 & 4.20 & 27.94 \\
\hline & LV2 & 45.44 & 20.96 & 4.66 & 0.92 & 1.78 & 7.36 & 6.44 & 31.43 \\
\hline & OY & 51.64 & 23.79 & 4.45 & 1.22 & 2.32 & 9.45 & 7.89 & 34.67 \\
\hline & GX & 48.39 & 12.95 & 4.55 & 0.90 & 1.75 & 12.40 & 7.40 & 31.85 \\
\hline & RQ & 26.68 & 15.57 & 3.98 & 0.67 & 1.15 & 6.32 & 4.82 & 17.89 \\
\hline \multirow{6}{*}{ 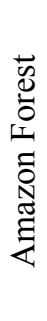 } & LA & 62.25 & 22.12 & 4.56 & 1.20 & 1.67 & 10.65 & 8.60 & 42.08 \\
\hline & LVA & 47.98 & 23.16 & 4.41 & 0.79 & 1.92 & 9.30 & 2.80 & 37.44 \\
\hline & $\mathrm{AC}$ & 41.74 & 19.41 & 4.87 & 0.68 & 1.42 & 6.34 & 2.59 & 30.78 \\
\hline & PVA & 47.44 & 18.56 & 4.26 & 0.59 & 2.02 & 7.80 & 2.67 & 34.96 \\
\hline & FX & 35.85 & 15.34 & 4.58 & 0.54 & 1.38 & 5.49 & 2.08 & 27.26 \\
\hline & $\mathrm{Sd}$ & 8.61 & 7.97 & 4.88 & 0.62 & 0.98 & 2.67 & 1.45 & 2.83 \\
\hline
\end{tabular}



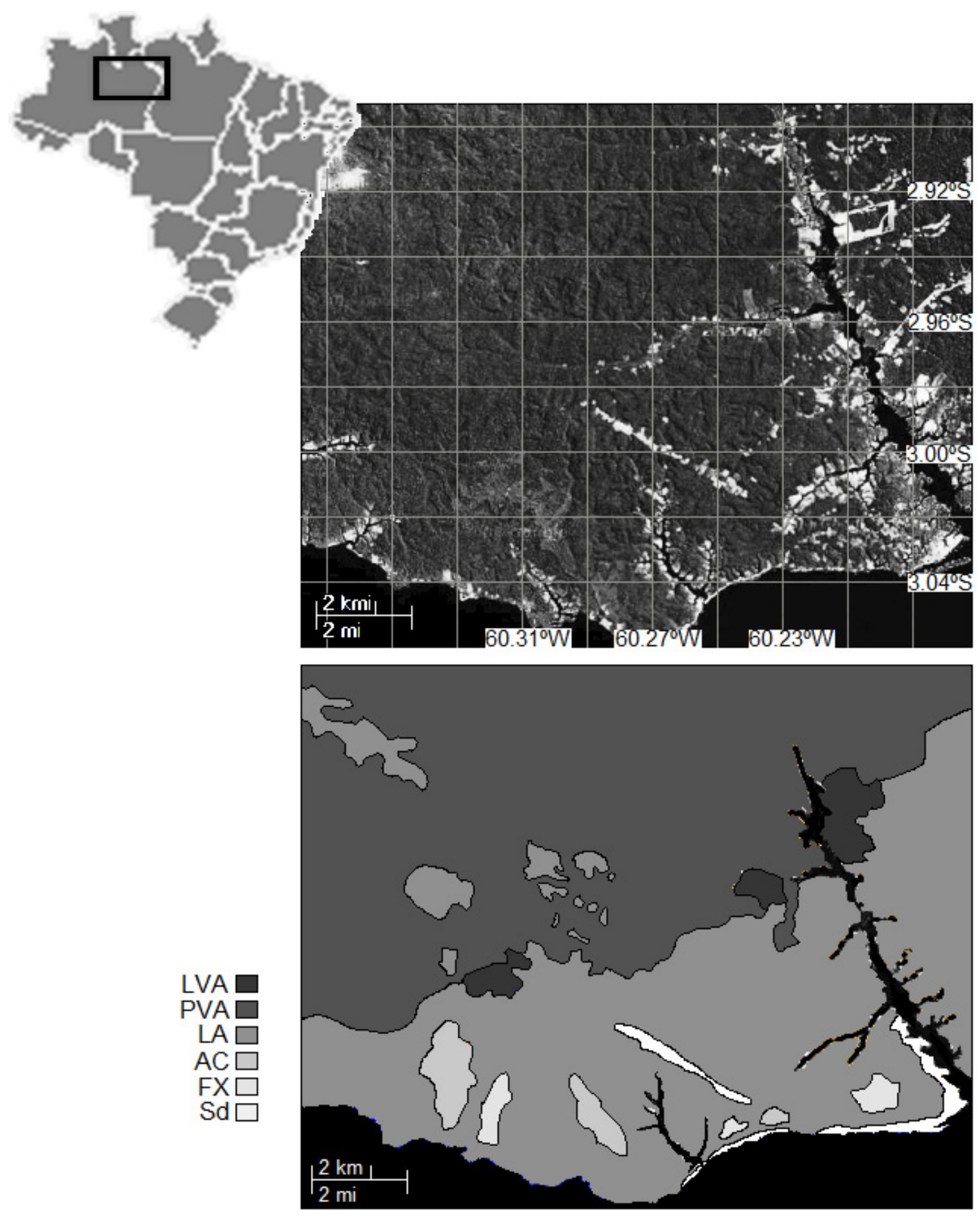

Figure 1. Study area in the Amazon rainforest with the chart of soils classification (Source: Google Earth and SiBCS modified with Archview Software) 

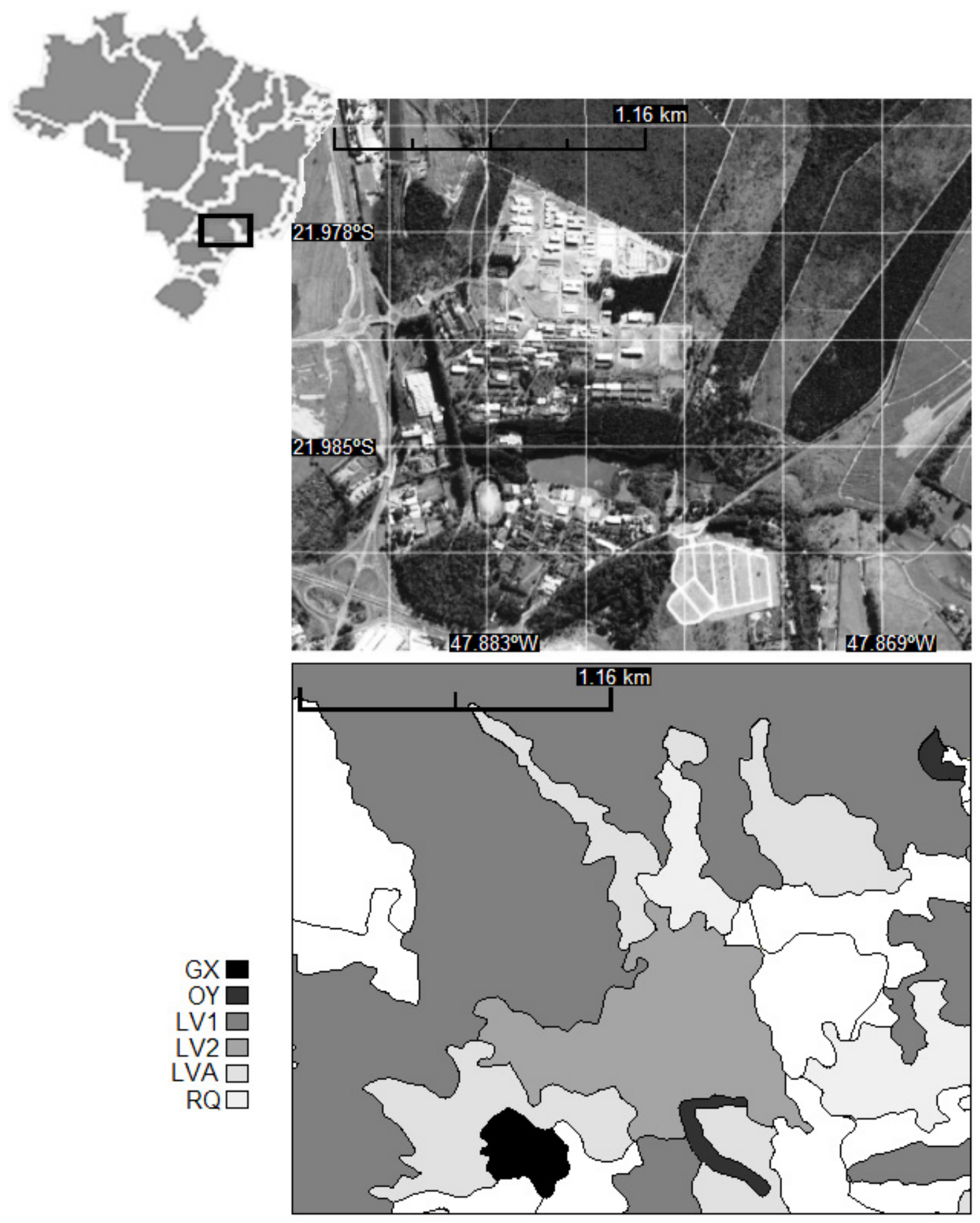

Figure 2. Study area in the Atlantic rainforest (Mata Atlântica) with the chart of soils classification (Source: Google Earth and SiBCS modified with Archview Software) 

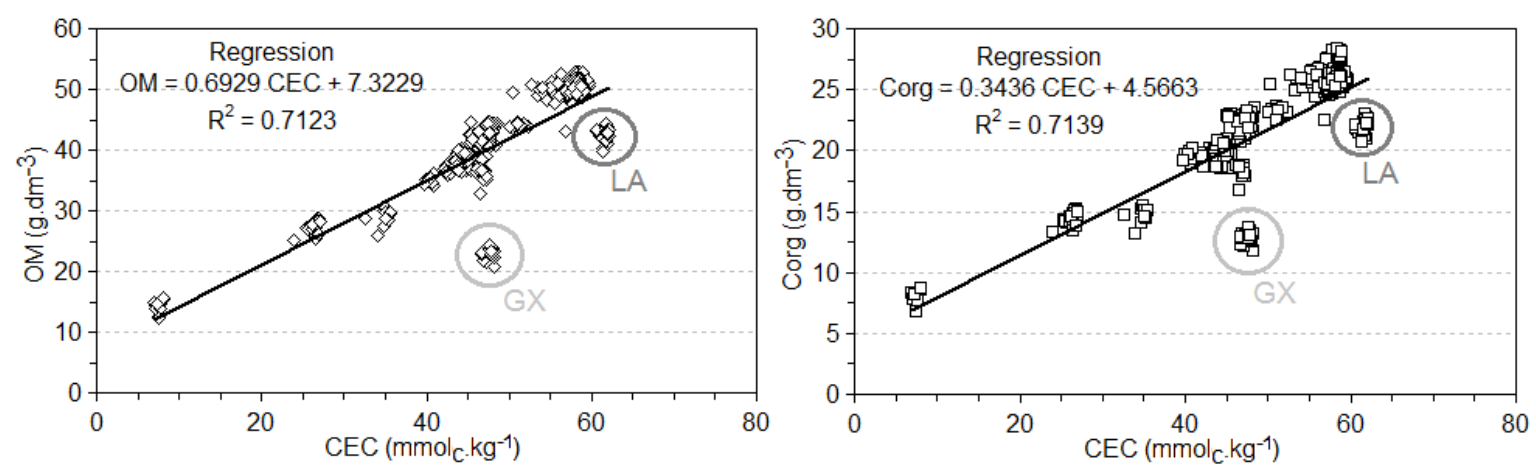

Figure 3. Pearson correlation analysis between CEC, organic matter $(\mathrm{OM})$ and organic carbon $\left(\mathrm{C}_{\mathrm{org}}\right)$ for soils sampled in the Amazon rainforest and Atlantic rainforest $(n=444$, degrees of freedom $=443,95 \%$ confidence interval $=0.81$ to 0.87 )
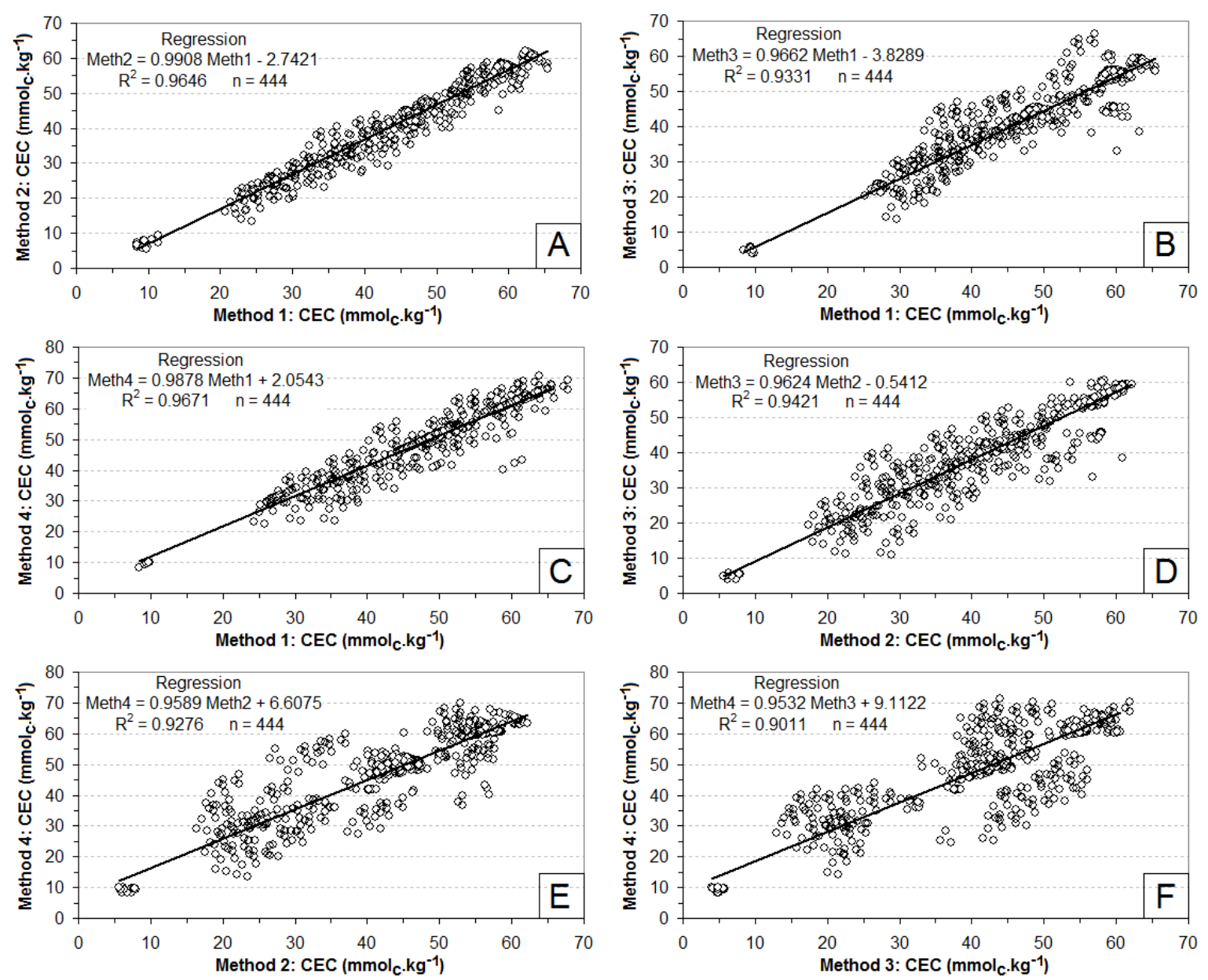

Figure 4. Pearson correlation analyses between the four methods tested for determination of cation exchange capacity - CEC 


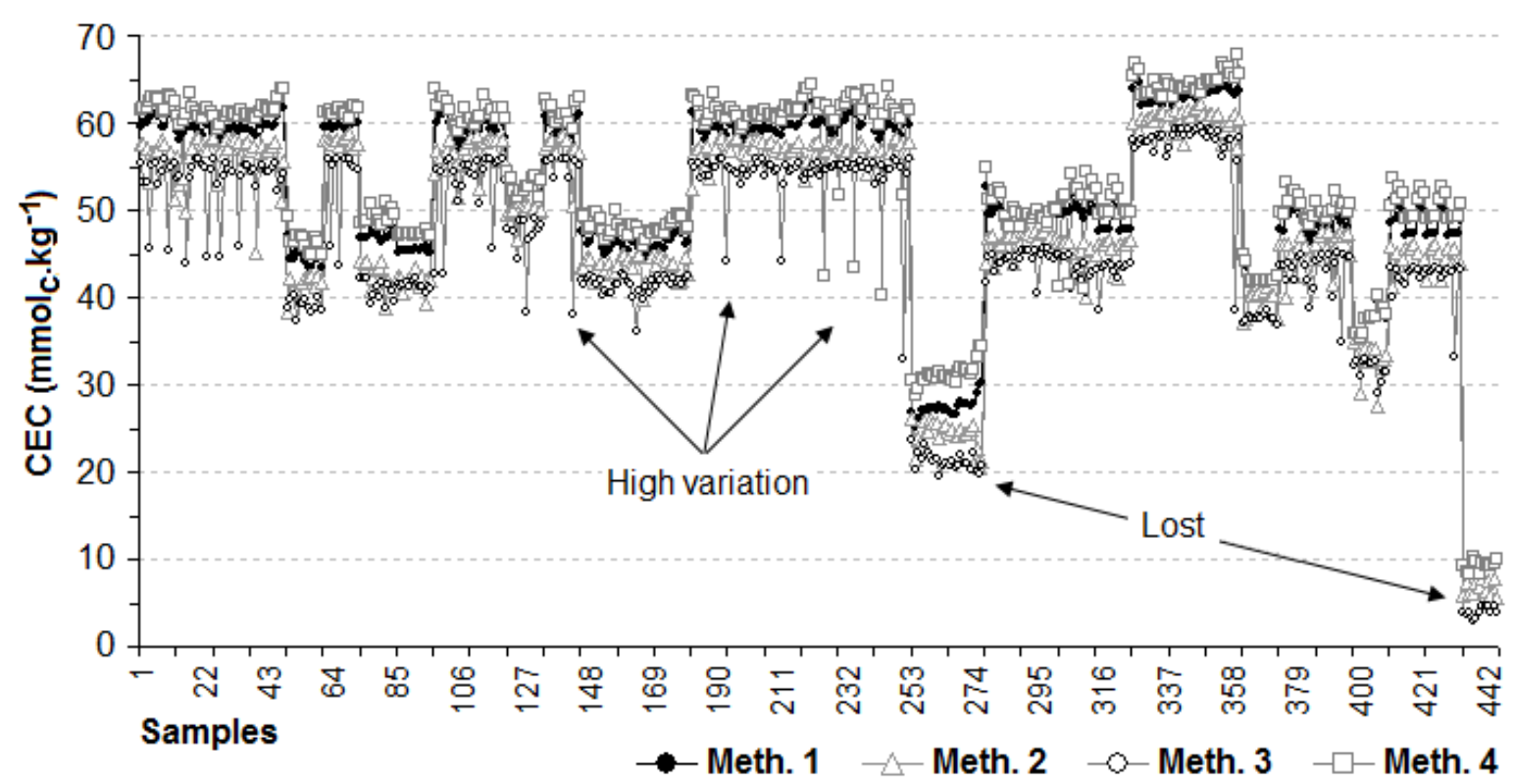

Figure 5. Sensitivity to detect the concentration of CEC $\left(\mathrm{mmol} \mathrm{kg}^{-1}\right)$ by the four methods tested for 37 sampling stations and 444 soil samples
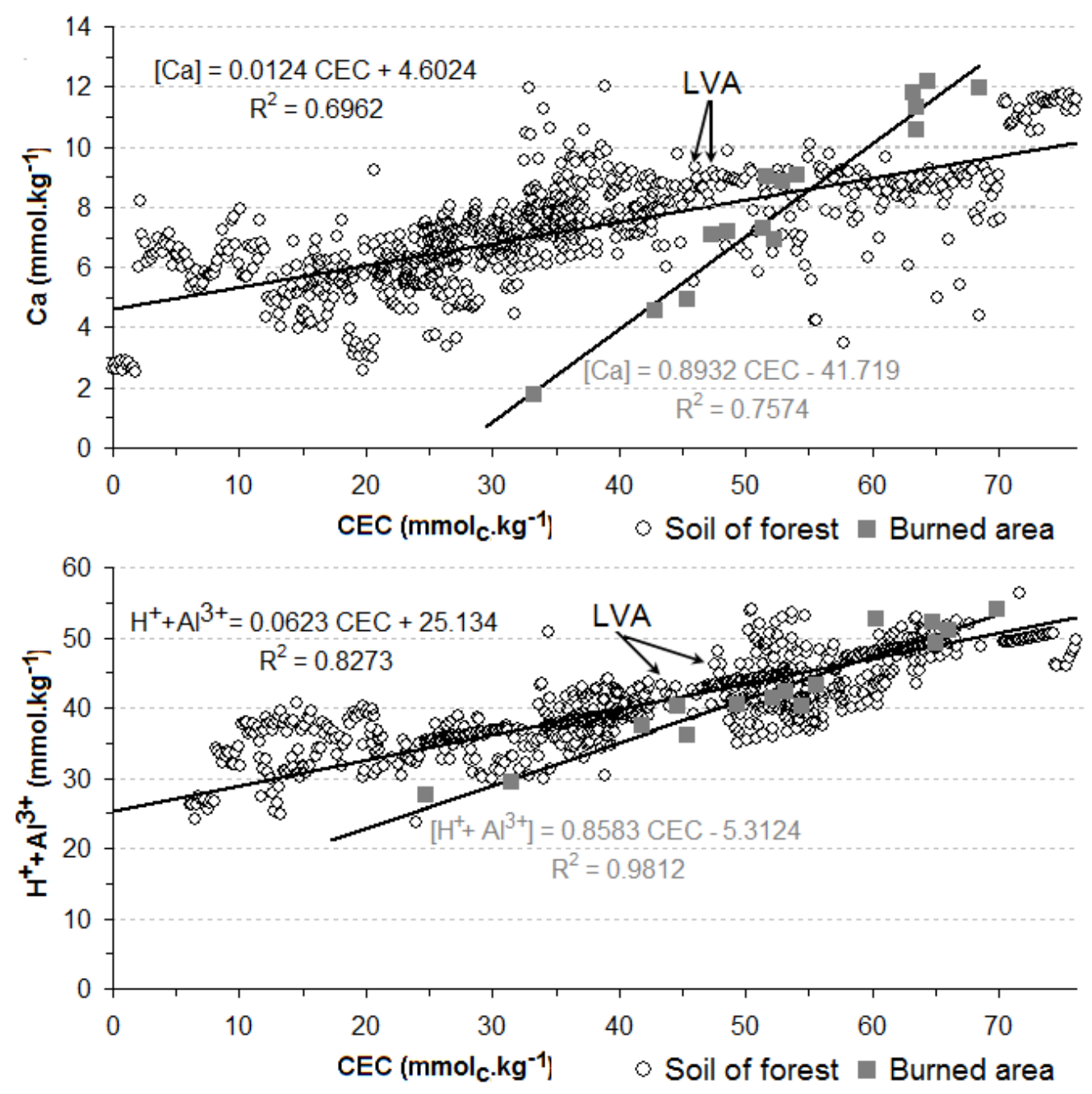

Figure 6. Linear regression analyses between $\mathrm{CEC}$ and the calcium and hydrogen/aluminum from natural sources in soils of the Amazon rainforest $(n=144)$ and LVA soil between 24 and 48 hours after burning $(n=15)$ 